\title{
SYNTHESIS AND CHARACTERIZATION OF THE SURFACE MODIFIED TITANIUM DIOXIDE/EPOXY NANOCOMPOSITES
}

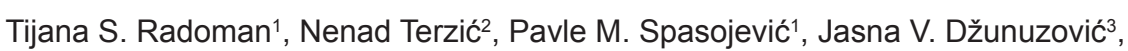
Aleksandar D. Marinković2 ${ }^{2}$ Katarina B. Jeremić2 ${ }^{2}$ Enis S. Džunuzović ${ }^{*}$

\footnotetext{
1 Innovation Center, Faculty of Technology and Metallurgy, University of Belgrade, Serbia

2 Faculty of Technology and Metallurgy, University of Belgrade, Serbia

3 Institute of Chemistry, Technology and Metallurgy (ICTM), Center of Chemistry, University of Belgrade, Serbia
}

$\mathrm{TiO}_{2}$ nanoparticles, obtained by acid catalyzed hydrolysis of titanium isopropoxide, were surface modified by three gallic acid esters with different hydrophobic part length: octyl, decyl and lauryl gallate, and then used to prepare $\mathrm{TiO}_{2}$ /epoxy nanocomposites. The characterization of the surface modified $\mathrm{TiO}_{2}$ nanoparticles was performed by FTIR and UV-Vis spectroscopy. The influence of different gallic acid esters and content of modified $\mathrm{TiO}_{2}$ nanoparticles on the glass transition temperature $(\mathrm{Tg})$, rheological, barrier and mechanical properties of the nanocomposites was investigated by DSC, DMA, water vapor permeability test and König pendulum. The presence of the surface modified $\mathrm{TiO}_{2}$ nanoparticles in epoxy resin caused the increase of $\mathrm{Tg}$ and decrease of the water vapor permeability. However, the length of the nonpolar gallate part showed no effect on $\mathrm{Tg}$ of the synthesized nanocomposites, while the increase of the nanofiller content resulted in the increase of $\mathrm{Tg}$. With increasing the hydrophobic part chain length of gallate ligand, the water vapor transmission rate decreased, while the hardness of the nanocomposites did not change.

\section{(ORIGINAL SCIENTIFIC PAPER)} UDC 678.743 .2

Keywords: $\mathrm{TiO}_{2}$ /epoxy nanocomposites, surface modification, gallic acid esters, water vapor permeability, König hardness

\section{Introduction}

Epoxy resins, one of the most important thermosetting polymers, have been extensively used in coatings, electronic materials, adhesives, as matrices for advanced composites, and so on [1-3]. Among different inorganic fillers used to improve the properties of polymer matrices, titanium dioxide is one of the most investigated [4-5]. However, commercial micrometer size inorganic pigments could have the adverse effect on the properties of crosslinked coatings, especially on adhesion of the coating to the substrate, can reduce the elasticity of the coating, its impact resistance, transparency, and resistance to abrasion and scratching and can cause delamination of the coating [6-9].

Because of the small size, nanoparticles have a high specific surface area and their presence can improve mechanical, optical, thermal and barrier properties of the epoxy coatings [10-14]. Such property improvement can be achieved by uniform distribution of nanoparticles through the polymer matrix, i.e. by preventing the aggregation of nanoparticles which can occur due to their high interfacial reactivity and high surface tension energy, and by improving the compatibility between nanoparticles and polymer, which is usually accomplished after the adequate surface modification of nanoparticles. The most common way to modify the surface of nanoparticles, control nanoparticles aggregation and stabilize the colloidal nanoparticles is to attach suitable organic groups to the surface atoms of nanoparticles [15-17]. After the appropriate surface modification, nanoparticles become hydrophobic, which can decrease their surface tension and lead to better miscibility and compatibility of nanoparticles with the polymer matrix [18]. Organic groups that can be used to attach ligands to the titanium dioxide surface are amine [19], ammonium [20] and different benzene derivatives, mostly catechol and salicylic acid [21-23]. Aromatic ligands with two or three adjacent phenolic $\mathrm{OH}$ groups (catechol, pyrogallol and gallic acid) can be adsorbed on the surface of $\mathrm{TiO}_{2}$ by forming chelating or bridging complexes with titanium ions on the surface [24-25]. In our previous works, $\mathrm{TiO}_{2}$ nanoparticles were surface modified with different alkyl gallates [26] and then incorporated into the poly (methyl mehacrylate) and epoxy matrix [27]. The length of the aliphatic part of the used gallates showed a great effect on dispersability of the surface modified $\mathrm{TiO}_{2}$ nanoparticles and on the properties of both matrices.

In this article, surface modification of $\mathrm{TiO}_{2}$ nanoparticles was performed with three gallic acid esters with different lengths of alkyl chains (octyl (8C), decyl (10C) and lauryl (12C) gallate). Surface modified $\mathrm{TiO}_{2}$ nanoparticles were characterized using Fourier transform infrared (FTIR) and ultraviolet-visible (UV-Vis) spectroscopy. The influence of different gallic acid esters used for surface modification and content of modified $\mathrm{TiO}_{2}$

*Author address: Enis S. Džunuzović, University of Belgrade, Karnegijeva 4, Belgrade, Serbia

E-mail: edzunuzovic@tmf.bg.ac.rs

The manuscript received: February, 23, 2015.

Paper accepted: April, 20, 2015. 
nanoparticles on the glass transition temperature, rheological, barrier and mechanical properties of epoxy resin was investigated.

\section{Materials and methods}

\section{Materials}

Titanium isopropoxide was obtained from TCI Europe. Gallic acid, octyl gallate (OG), lauryl gallate (LG), decyl alcohol and 2-propanol were obtained from Sigma-Aldrich. Decyl gallate (DG) was synthesized by esterification of galic acid with decyl alcohol using the same synthetic procedure described elsewhere [28]. Epoxy resin (ER), CHS-EPOXY $210 \times 75$, was purchased from Spolchemie. The curing agent, EPIKURE 3115 X 70 was purchased from Momentive. All chemicals were used as received without further purification.

Preparation and surface modification of $\mathrm{TiO}_{2}$ nanoparticles

The $\mathrm{TiO}_{2}$ colloid was prepared by hydrolysis of titanium isopropoxide at $80{ }^{\circ} \mathrm{C}$ under a stream of dry nitrogen for $8 \mathrm{~h}$, according to the procedure described in literature $[27,29]$. The surface modification of $\mathrm{TiO}_{2}$ colloidal nanoparticles with octyl gallate $\left(\mathrm{TiO}_{2}-\mathrm{OG}\right)$, decyl gallate $\left(\mathrm{TiO}_{2}-\mathrm{DG}\right)$, and lauryl gallate $\left(\mathrm{TiO}_{2}-\mathrm{LG}\right)$ was performed in the same manner. As an example, the modification of $\mathrm{TiO}_{2}$ nanoparticles with LG is described. Lauryl gallate $(0.1136 \mathrm{~g})$ was dissolved in $15 \mathrm{ml}$ of the chloroform and methanol mixture (4:1 vol./vol.). $\mathrm{TiO}_{2}$ colloid solution $(2 \mathrm{ml})$ was diluted ten times with deionized water and mixed with the prepared lauryl gallate solution in a separatory funnel. After shaking for a short time, a red chloroform phase, containing $\mathrm{TiO}_{2}$ particles surface modified with lauryl gallate $\left(\mathrm{TiO}_{2}-\mathrm{LG}\right)$, separated from the aqueous phase. The obtained red chloroform solution was drop-wise added to a 100 times larger volume of methanol to remove residual free lauryl gallate molecules. The surface modified $\mathrm{TiO}_{2}$ particles with lauryl gallate were separated by centrifugation and redispersed in chloroform for further usage.

Preparation of $\mathrm{TiO}_{2}$ /epoxy nanocomposite films

The commercially available epoxy resin CHS-EPOXY $210 \times 75$ was used as polymer matrix and cured with EPIKURE $3115 \times 70$ hardener using a weight ratio of 100:35. The nanocomposites with 1 wt. $\%$ of $\mathrm{TiO}_{2}$, $\left(\mathrm{TiO}_{2}-\right.$ OG1.0/ER, $\mathrm{TiO}_{2}-\mathrm{DG} 1.0 / \mathrm{ER}$ and $\mathrm{TiO}_{2}$-LG1.0/ER), by the total weight of epoxy resin and its hardener, were prepared by adding the appropriate amount of the surface modified $\mathrm{TiO}_{2}$ nanoparticles $\left(\mathrm{TiO}_{2}-\mathrm{OG}, \mathrm{TiO}_{2}-\mathrm{DG}\right.$ and $\mathrm{TiO}_{2}-\mathrm{LG}$, respectively) dispersed in chloroform to epoxy resin and after that a corresponding amount of curing agent EPIKURE 3115 X 70 was added. The obtained mixture was mixed in the ultrasonic bath (Sonorex Digitec) for $10 \mathrm{~min}$. The nanocomposites with 0.5 and $2 \mathrm{wt} . \%$ of $\mathrm{TiO}_{2}-$ LG $\left(\mathrm{TiO}_{2}-\mathrm{LG} 0.5 / \mathrm{ER}\right.$ and $\left.\mathrm{TiO}_{2}-\mathrm{LG} 2.0 / \mathrm{ER}\right)$ were prepared in the same manner by adding the appropriate amount of $\mathrm{TiO}_{2}-\mathrm{LG}$ nanoparticles to the epoxy resin. In order to prepare films of uniform thickness, the dispersions were drawn in films on glass plates with wire-wound rods. The dispersions were also cured in Teflon molds (dimensions $63 \times 12 \times 2 \mathrm{~mm}$ ) for DMA measurements. All samples were cured at room temperature for 21 days.

\section{Characterization of nanoparticles}

The size and shape of $\mathrm{TiO}_{2}$ nanoparticles were determined by the transmission electron microscopy (TEM, JEOL 1200EX). The FTIR spectra of dry, unmodified and modified $\mathrm{TiO}_{2}$ nanoparticles were recorded on a FTIR spectrophotometer (Bomem MB 100) in the form of $\mathrm{KBr}$ pellets. The absorption spectra of unmodified and modified $\mathrm{TiO}_{2}$ and prepared nanocomposites were recorded on a UV-Vis spectrophotometer (Perkin-Elmer Lambda-5).

\section{Characterization of nanocomposites}

Differential scanning calorimetry (DSC) was used to determine the glass transition temperature, $\mathrm{Tg}$, of epoxy film and polymer nanocomposites. The samples for DSC measurements were cut from the films cured on the glass plates. The films were pulled off after staying overnight in water and then dried in the vacuum oven for $2 \mathrm{~h}$ at $100{ }^{\circ} \mathrm{C}$. All measurements were performed on a Perkin Elmer DSC-2 instrument in a nitrogen atmosphere, at the heating rate of $20^{\circ} \mathrm{C} / \mathrm{min}$.

The water vapor transfer through the polymer films was determined by the standard gravimetric method (ASTM D1653-13) using the permeability test dish (BYKGardner permeability cup). The desiccant method was used and measurements were carried out under the conditions of constant relative humidity of $85 \%$. The water vapor transmission rate (WVTR) was calculated using the equation 1 :

$$
\text { WVTR }=\frac{\Delta m}{t A}
$$

where $A$ is the surface area of the polymer film through which the water vapor can pass during the time $t$, while $\Delta m$ is the mass of transported water.

The dependence of the storage modulus, loss modulus and the loss factor on temperature at a constant frequency was determined by the dynamic mechanical analysis (DMA) using TA Instruments SDT Q600 operating in the temperature sweep mode. All measurements were performed in the temperature range $25-150{ }^{\circ} \mathrm{C}$, at a frequency of $1 \mathrm{~Hz}$, and deformation of $0.1 \%$.

The thickness of $\mathrm{TiO}_{2}$-epoxy nanocomposite dry film was determined by thickness gauge (Byko-test $4500 \mathrm{Fe} /$ NFe, BYK-Gardner).

Hardness of nanocomposites was determined by the pendulum hardness tester using König pendulum (BYKGardner). Hardness testing was performed in three different places on the coating and the average value of the number of oscillations was used as the hardness of the film. 


\section{Results and discussions}

Characterization of the $\mathrm{TiO}_{2}$ nanoparticles

$\mathrm{TiO}_{2}$ nanoparticles in the anatase crystalline form were prepared by acid catalyzed hydrolysis of titanium isopropoxide [29]. The average particle size was estimated by TEM (Figure 1), and it was found that the particles are roughly spherical in shape with the average particle size of $3.9 \pm 0.9 \mathrm{~nm}$ [27].

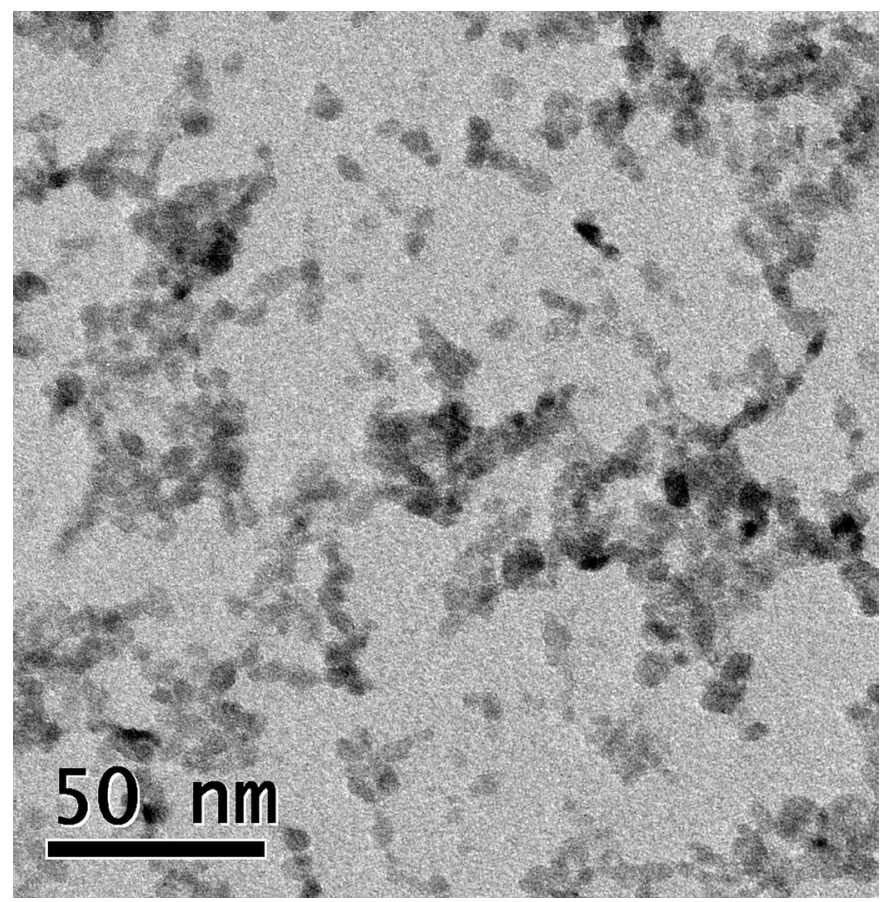

Figure 1. TEM image of $\mathrm{TiO}_{2}$ nanoparticles

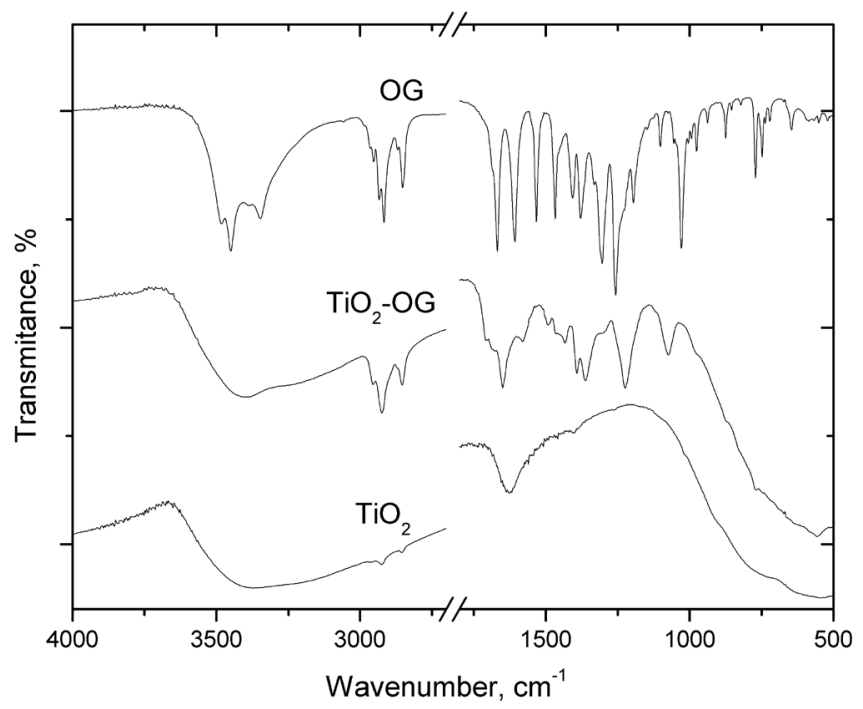

Figure 2. FTIR spectra of octyl gallate (OG), $\mathrm{TiO}_{2}$ nanoparticles and $\mathrm{TiO}_{2}$ nanoparticles modified with octyl gallate $\left(\mathrm{TiO}_{2}-\mathrm{OG}\right)$

The surface modification of $\mathrm{TiO}_{2}$ nanoparticles was performed in order to enable the nanoparticles tran- sfer from the aqueous to the organic phase. Three gaIlic acid esters with different lengths of the hydrophobic part (octyl, decyl and lauryl gallate) were used for surface modification of the synthesized $\mathrm{TiO}_{2}$ nanoparticles. Charge transfer complex (CTC) between the $\mathrm{TiO}_{2}$ nanoparticles and formed alkyl gallates was confirmed by FTIR and UV-Vis spectroscopy. FTIR spectra of octyl galatte, dried $\mathrm{TiO}_{2}$ and $\mathrm{TiO}_{2}$ nanoparticles modified with octyl gallate are shown in Figure 2 .

The spectrum of dried $\mathrm{TiO}_{2}$ nanoparticles contains a wide band in a range from 3700 to $3000 \mathrm{~cm}^{-1}$, assigned to the stretching vibrations of surface $\mathrm{OH}$ groups and symmetric and asymmetric vibrations of the surface adsorbed water. The bands between 2960 and $2850 \mathrm{~cm}^{-1}$ are attributed to the organic residues formed during the synthesis of colloids. The band at $1630 \mathrm{~cm}^{-1}$ corresponds to the bending vibration of adsorbed water.

In the FTIR spectrum of OG, characteristic bands at 3450 and $3350 \mathrm{~cm}^{-1}$ correspond to the $\mathrm{OH}$ stretching vibrations. The bands at 2950 and $2870 \mathrm{~cm}^{-1}$ originate from asymmetric and symmetric stretching vibrations of $\mathrm{C}-\mathrm{H}$ bond from a methyl group, while the bands at 2930 and $2850 \mathrm{~cm}^{-1}$ correspond to the asymmetric and symmetric stretching vibration of $\mathrm{C}-\mathrm{H}$ bond of a methylene group. The band at $1670 \mathrm{~cm}^{-1}$ is ascribed to stretching vibrations of ester carbonyl groups, and the bands at 1608,1533 , and $1408 \mathrm{~cm}^{-1}$ are assigned to aromatic ring stretching vibrations. The band at $1465 \mathrm{~cm}^{-1}$ is due to the aliphatic $\mathrm{C}-\mathrm{H}$ bending and aromatic ring stretching vibrations and the band at $1379 \mathrm{~cm}^{-1}$ is due to $\mathrm{C}-\mathrm{O}$ stretching vibrations of the phenolic group. The band at $1330 \mathrm{~cm}^{-1}$ corresponding to the in-plane $\mathrm{OH}$ bending vibration is overlapped with the band at $1305 \mathrm{~cm}^{-1}$, assigned to $\mathrm{C}-\mathrm{O}$ stretching vibrations of the phenolic group. Other characteristic bands at 1260, 1196 and $1030 \mathrm{~cm}^{-1}$ can be assigned to $\mathrm{C}(=\mathrm{O})-\mathrm{O}$ stretching vibrations of ester groups, in-plane bending vibrations of the phenolic group and $\mathrm{O}-\mathrm{C}-\mathrm{C}$ stretching vibrations of the ester group, respectively.

In the FTIR spectrum of $\mathrm{TiO}_{2}$ nanoparticles surface modified with OG, characteristic bands at 3450,3350 and $1196 \mathrm{~cm}^{-1}$ completely disappeared. The bands corresponding to the $\mathrm{C}(=\mathrm{O})-\mathrm{O}$ bond and $\mathrm{O}-\mathrm{C}-\mathrm{C}$ vibrations became broader and shifted to lower and higher frequencies, respectively. The band at $1379 \mathrm{~cm}^{-1}$, corresponding to $\mathrm{C}-\mathrm{O}$ stretching vibrations of the phenolic group became broader and shifted towards lower frequencies. Also, the band at $1304 \mathrm{~cm}^{-1}$ did not disappear completely, but its intensity was drastically reduced. According to the FTIR results, one $\mathrm{OH}$ group of gallic acid esters remained unbounded, while OG was bonded to the surface $\mathrm{Ti}$ atoms through the adjacent $\mathrm{OH}$ groups forming a binuclear (bridging) complex. Characteristic bands observed in the FTIR spectra of $\mathrm{TiO}_{2}$ nanoparticles modified with decyl and lauril gallate are similar in shape and position as in the FTIR spectra of $\mathrm{TiO}_{2}$ nanoparticles modified with octyl gallate.

In addition to the results obtained from FTIR spectro- 
scopy, the formation of the charge transfer complex between the surface of $\mathrm{TiO}_{2}$ nanoparticles and gallic acid esters was also confirmed by UV-Vis spectroscopy. The formation of CTC between alkyl gallates and $\mathrm{TiO}_{2}$ is the reason for the appearance of red color of the obtained dispersions. The absorption spectra of the aqueous $\mathrm{TiO}_{2}$ solution and $\mathrm{TiO}_{2}-\mathrm{OG}, \mathrm{TiO}_{2}-\mathrm{DG}$ and $\mathrm{TiO}_{2}-\mathrm{LG}$ solutions in chloroform are given in Figure 3 . The absorption spectra of $\mathrm{TiO}_{2}$ nanoparticles surface modified with gallates are shifted to higher wavelengths in comparison to the absorption spectrum of aqueous $\mathrm{TiO}_{2}$. The absorption of the surface modified $\mathrm{TiO}_{2}$ nanoparticles starts at around $650 \mathrm{~nm}$ and the absorption of aqueous $\mathrm{TiO}_{2}$ starts at around $380 \mathrm{~nm}$. This significant shift of the absorption spectra indicates the reaction of gallic acid esters with surface $\mathrm{Ti}$ atoms of nanoparticles and the formation of CTC [26, 30]. However, the obtained results revealed that the hydrophobic part length of gallates used for the surface modification of $\mathrm{TiO}_{2}$ nanoparticles had no significant influence on the position of the absorption spectra of $\mathrm{TiO}_{2}$ nanoparticles.

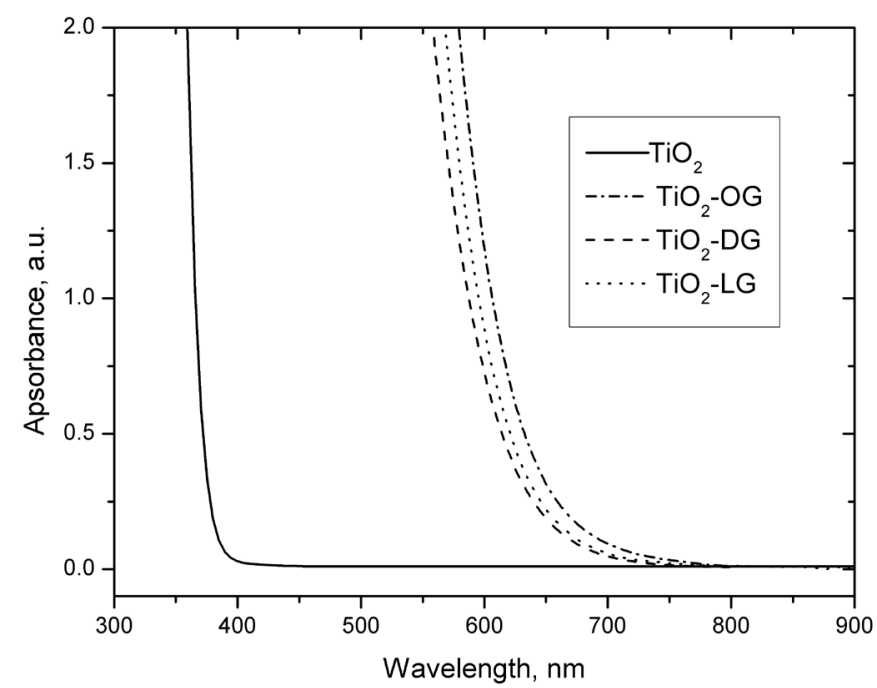

Figure 3. The absorption spectra of the aqueous $\mathrm{TiO}_{2}$ colloid solution and solutions of $\mathrm{TiO}_{2}-\mathrm{OG}, \mathrm{TiO}_{2}-\mathrm{DG}$ and $\mathrm{TiO}_{2}$-LG in chloroform

UV-Vis spectroscopy of $\mathrm{TiO}_{2} /$ epoxy nanocomposites

The presence of the surface modified $\mathrm{TiO}_{2}$ nanoparticles in the epoxy matrix was investigated by UV-Vis spectroscopy. The absorption spectra of pure epoxy resin and prepared $\mathrm{TiO}_{2}$ /epoxy nanocomposites films are presented in Figure 4. From the obtained results it can be observed that surface modified $\mathrm{TiO}_{2}$ nanopa-rticles are present in an unchanged form in the epoxy matrix. The increase of the hydrophobic part length of gallates used for the surface modification of $\mathrm{TiO}_{2}$ nanoparticles induced red shift of the nanocomposites absorption spectra at higher wavelengths (Figure 4a). Also, the increase of the $\mathrm{TiO}_{2}$-LG content shifted the absorption spectra of prepared nanocomposites to higher wavelengths (Fig- ure $4 b)$.
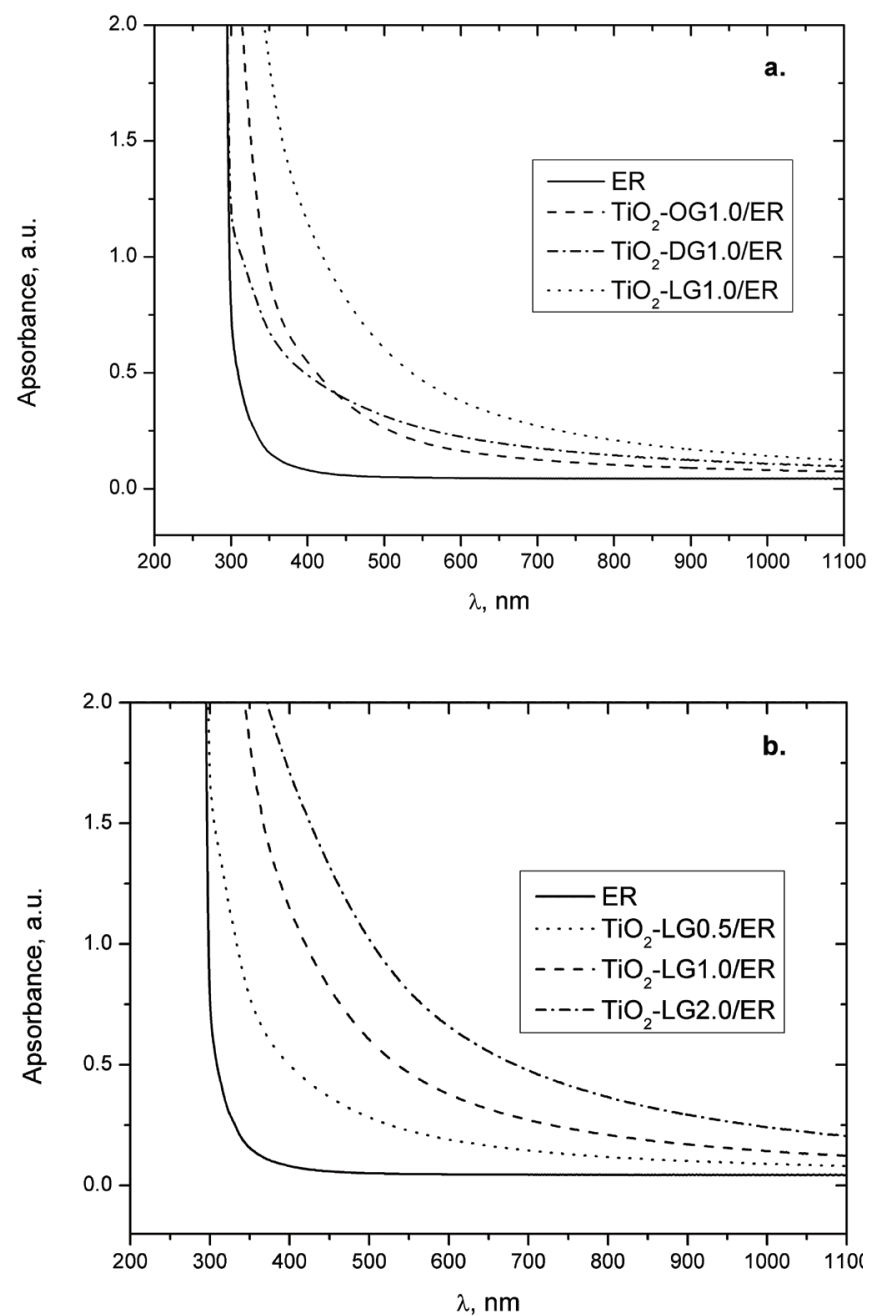

Figure 4. The absorption spectra of epoxy resin and a) $\mathrm{TiO}_{2}-$ OG1.0/ER, $\mathrm{TiO}_{2}$-DG1.0/ER and $\mathrm{TiO}_{2}$-LG1.0/ER and b) $\mathrm{TiO}_{2}$ LG0.5/ER, $\mathrm{TiO}_{2}$-LG1.0/ER and $\mathrm{TiO}_{2}$-LG2.0/ER nanocomposites

DSC analysis of the synthesized $\mathrm{TiO}_{2}$ /epoxy nanocomposites

The influence of the surface modified $\mathrm{TiO}_{2}$ nanoparticles on the glass transition temperature of $\mathrm{TiO}_{2} /$ epoxy nanocomposites was determined from the DSC results. DSC thermograms of crosslinked neat epoxy resin, nanocomposites containing $1.0 \mathrm{wt} \%$ of the surface modified $\mathrm{TiO}_{2}$ nanoparticles and nanocomposites prepared with different contents of lauryl gallate are shown in Figure 5. The glass transition temperature of the investigated samples was obtained as the peak maximum of the heat flow first derivative and the determined values are shown in Table 1. 

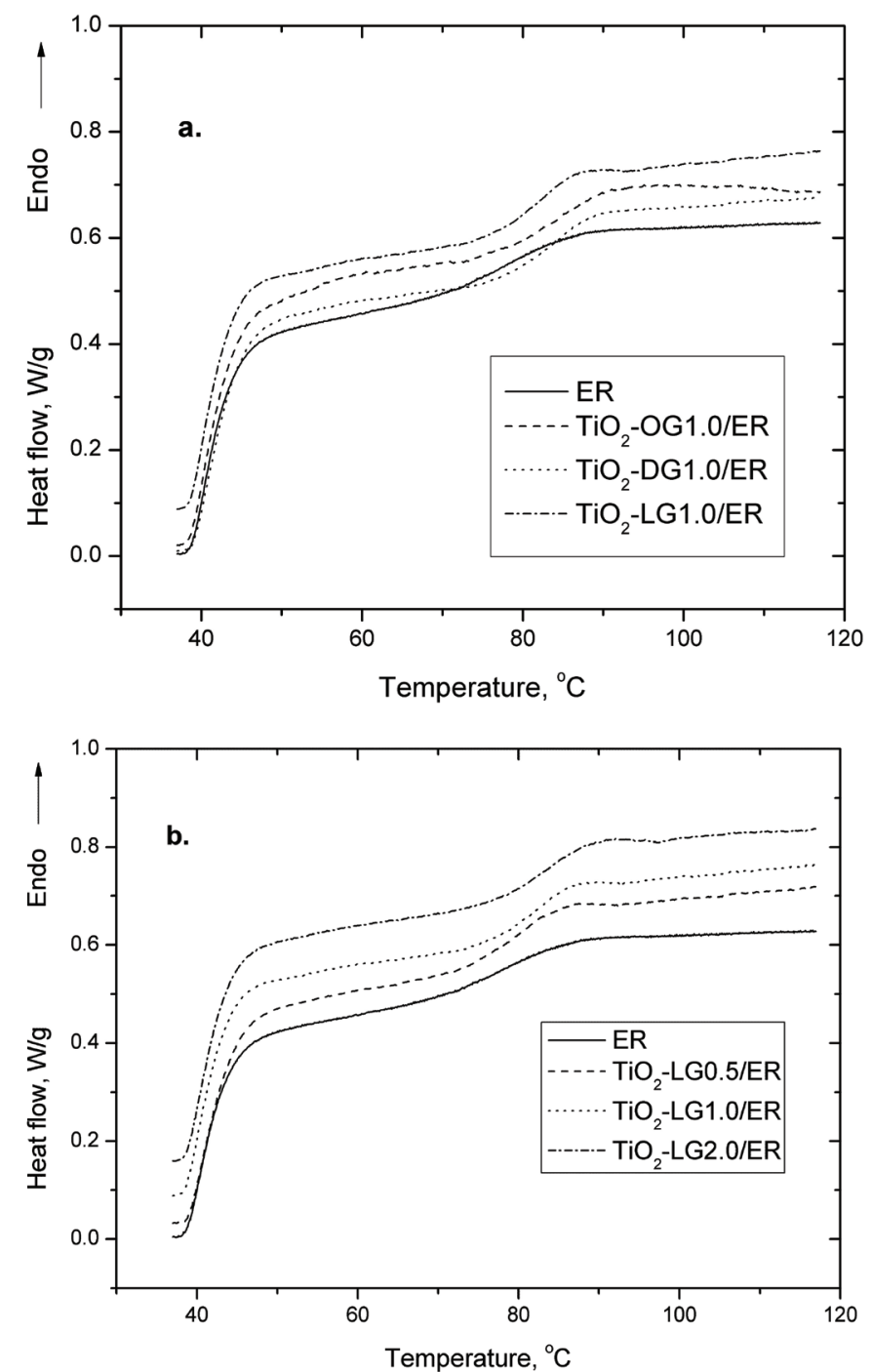

Figure 5. DSC thermograms of the examined epoxy resin and a) $\mathrm{TiO}_{2}-\mathrm{OG} 1.0 / \mathrm{ER}, \mathrm{TiO}_{2}-\mathrm{DG} 1.0 / \mathrm{ER}$ and $\mathrm{TiO}_{2}-\mathrm{LG} 1.0 / \mathrm{ER}$ and b) $\mathrm{TiO}_{2}$-LG0.5/ER, $\mathrm{TiO}_{2}$-LG1.0/ER and $\mathrm{TiO}_{2}$-LG2.0/ER nanocomposites

Incorporation of the surface modified $\mathrm{TiO}_{2}$ nanoparticles led to the increase of $\mathrm{Tg}$ of epoxy resin, indicating the presence of attractive interactions between $\mathrm{TiO}_{2}$ nanoparticles and the polymer matrix and the reduction of the mobility of segments at the interface between the polymer matrix and $\mathrm{TiO}_{2}$ nanoparticles [31-33]. Also, curing reactions may cause partial aminolysis of gallate ester groups and amide formation, which led to the chemical bonding of nanoparticles to the polymer matrix and the increase of the $T g$ value. According to the obtained results it can be concluded that the chain length of the hydrophobic part of gallates used for surface modification of $\mathrm{TiO}_{2}$ nanoparticles has no influence on the $\mathrm{Tg}$ value, while the increase of the $\mathrm{TiO}_{2}-\mathrm{LG}$ content induced a slight increase of $T g$.
Table 1. Values of the glass transition temperature determined by DSC analysis, $T g(\mathrm{DSC})$, and DMA, $T g\left(G^{n}\right)$ and $T g(\tan \delta)$, and values of $G^{\prime}$ at $120^{\circ} \mathrm{C}$ of the examined samples

\begin{tabular}{lcccc}
\hline Sample & $T_{\mathrm{g}}$ (DSC), ${ }^{\circ} \mathrm{C}$ & $T_{\mathrm{g}}\left(\mathrm{G}^{\prime \prime}\right),{ }^{\circ} \mathrm{C}$ & $T_{\mathrm{g}}(\tan \delta),{ }^{\circ} \mathrm{C}$ & $\begin{array}{c}\mathrm{G} \times 10^{-6}, \\
\mathrm{MPa} \\
\left(120^{\circ} \mathrm{C}\right)\end{array}$ \\
\hline ER & 79 & 66 & 87 & 4.54 \\
$\mathrm{TiO}_{2}$-OG1.0/ER & 85 & 71 & 89 & 4.85 \\
$\mathrm{TiO}_{2}$-DG1.0/ER & 84 & 69 & 89 & 4.06 \\
$\mathrm{TiO}_{2}$-LG0.5/ER & 80 & 69 & 88 & 3.94 \\
$\mathrm{TiO}_{2}$-LG1.0/ER & 83 & 69 & 87 & 3.92 \\
$\mathrm{TiO}_{2}$-LG2.0/ER & 84 & 71 & 91 & 4.22 \\
\hline
\end{tabular}

DMA of synthesized $\mathrm{TiO}_{2} /$ epoxy nanocomposites

A dynamic mechanical analysis of the prepared samples was performed to determine the influence of the surface modified $\mathrm{TiO}_{2}$ nanoparticles on thermo-mechanical properties of the cured epoxy/TiO 2 nanocomposites. The dependence of the storage modulus, $G^{\prime}$, loss modulus, $G$ ", and loss factor, tan $\delta$ on temperature are shown in Figures 6, 7 and 8, respectively.

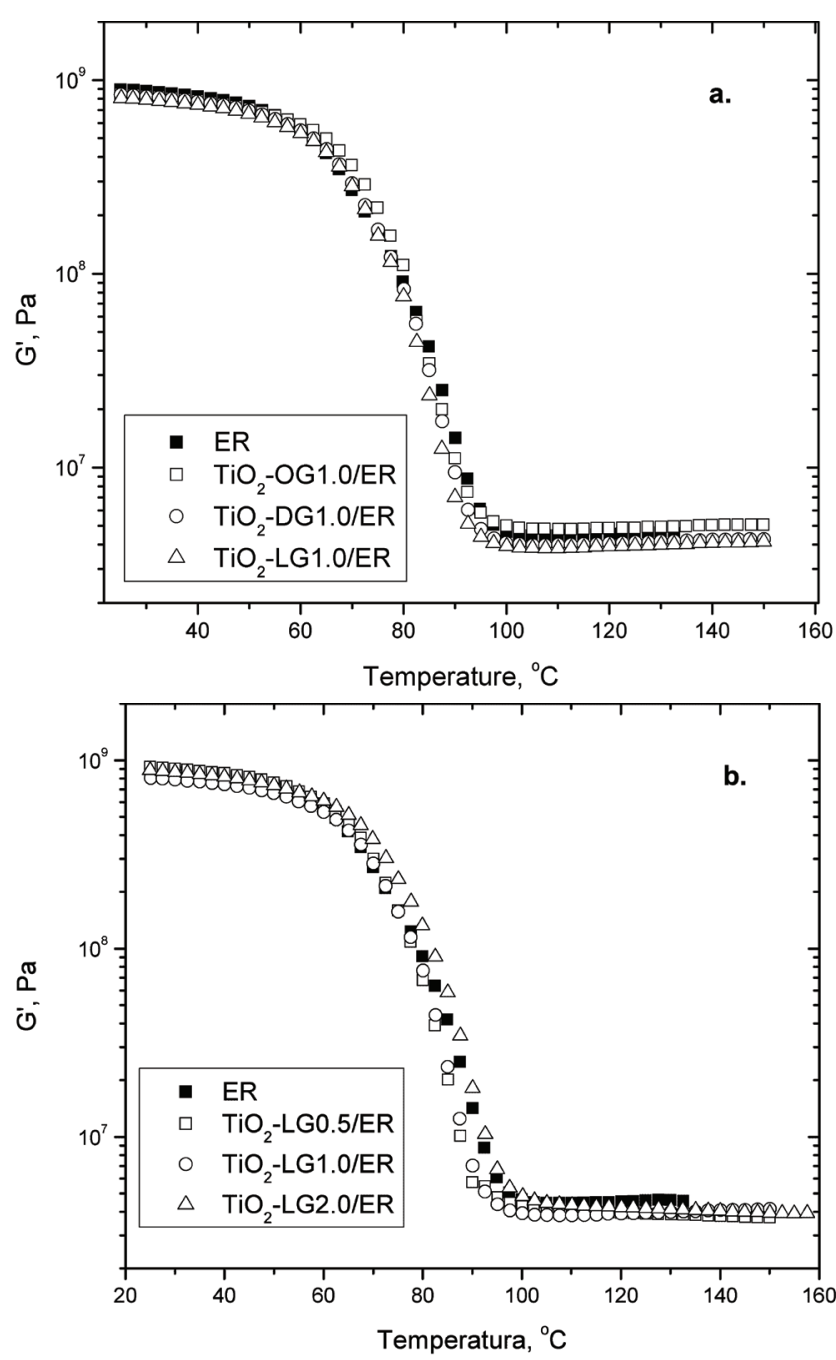

Figure 6. The dependence of storage modulus, $G^{\prime}$, on the temperature for epoxy resin and a) $\mathrm{TiO}_{2}-\mathrm{OG} 1.0 / \mathrm{ER}, \mathrm{TiO}_{2}-\mathrm{DG} 1.0 /$ $\mathrm{ER}$ and $\mathrm{TiO}_{2}$-LG1.0/ER and b) $\mathrm{TiO}_{2}$-LG0.5/ER, $\mathrm{TiO}_{2}$-LG1.0/ER and $\mathrm{TiO}_{2}$-LG2.0/ER nanocomposites 
From the results presented in Figure 6 it can be observed that all investigated samples reached rubbery plateau at temperatures higher than $100{ }^{\circ} \mathrm{C}$. The characteristic of the rubbery plateau is that the values of the storage modulus do not depend on the temperature and therefore the $G^{\prime}$ values of the examined samples determined at $120^{\circ} \mathrm{C}$ are listed in Table 1 . According to the result given in Figure 6 and Table 1 there is no significant difference in the values of the storage modulus between the investigated nanocomposites and pure epoxy resin in the rubbery plateau, indicating that the crosslink density of all samples is approximately the same.
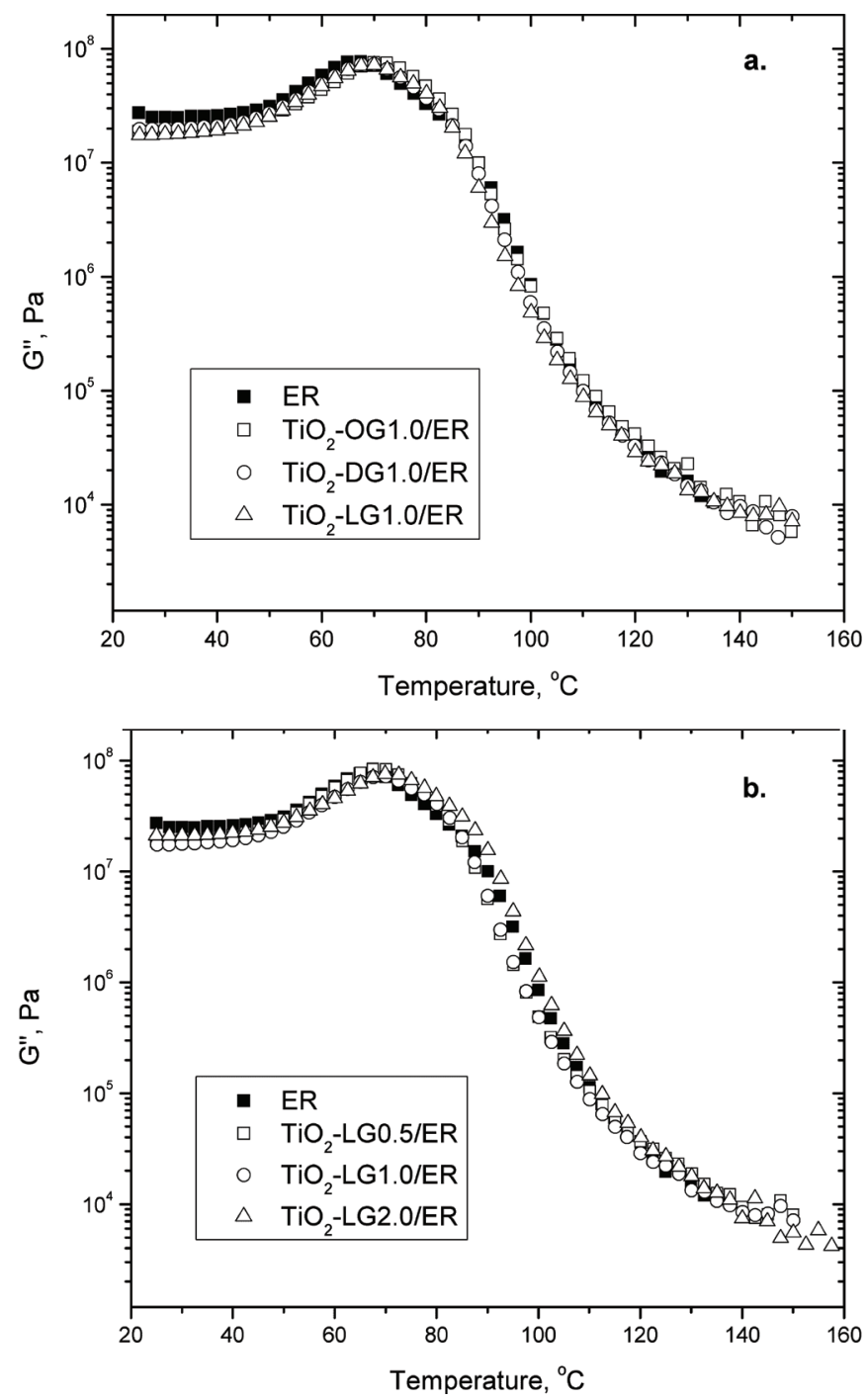

Figure 7. The dependence of loss modulus, G", on the temperature of epoxy resin and a) $\mathrm{TiO}_{2}$-OG1.0/ER, $\mathrm{TiO}_{2}$-DG1.0/ER and $\mathrm{TiO}_{2}-\mathrm{LG} 1.0 / \mathrm{ER}$ and b) $\mathrm{TiO}_{2}-\mathrm{LG} 0.5 / \mathrm{ER}, \mathrm{TiO}_{2}-\mathrm{LG} 1.0 / \mathrm{ER}$ and $\mathrm{TiO}_{2}$-LG2.0/ER nanocomposites

The values of the glass transition temperature of pure epoxy resin and synthesized nanocomposites, determined as a maximum of the temperature dependences of G" (Figure 7) and tan $\delta$ (Figure 8), are listed in Table 1. It can be observed that nanocomposites have a higher glass transition temperature than neat epoxy resin and that the length of the hydrophobic part of gallates has no effect on the glass transition temperature of the synthesized nanocomposites, while with increasing the nanofiller content the glass transition temperature slightly increased. The obtained trend for $T g$ values is consistent with the DSC results.
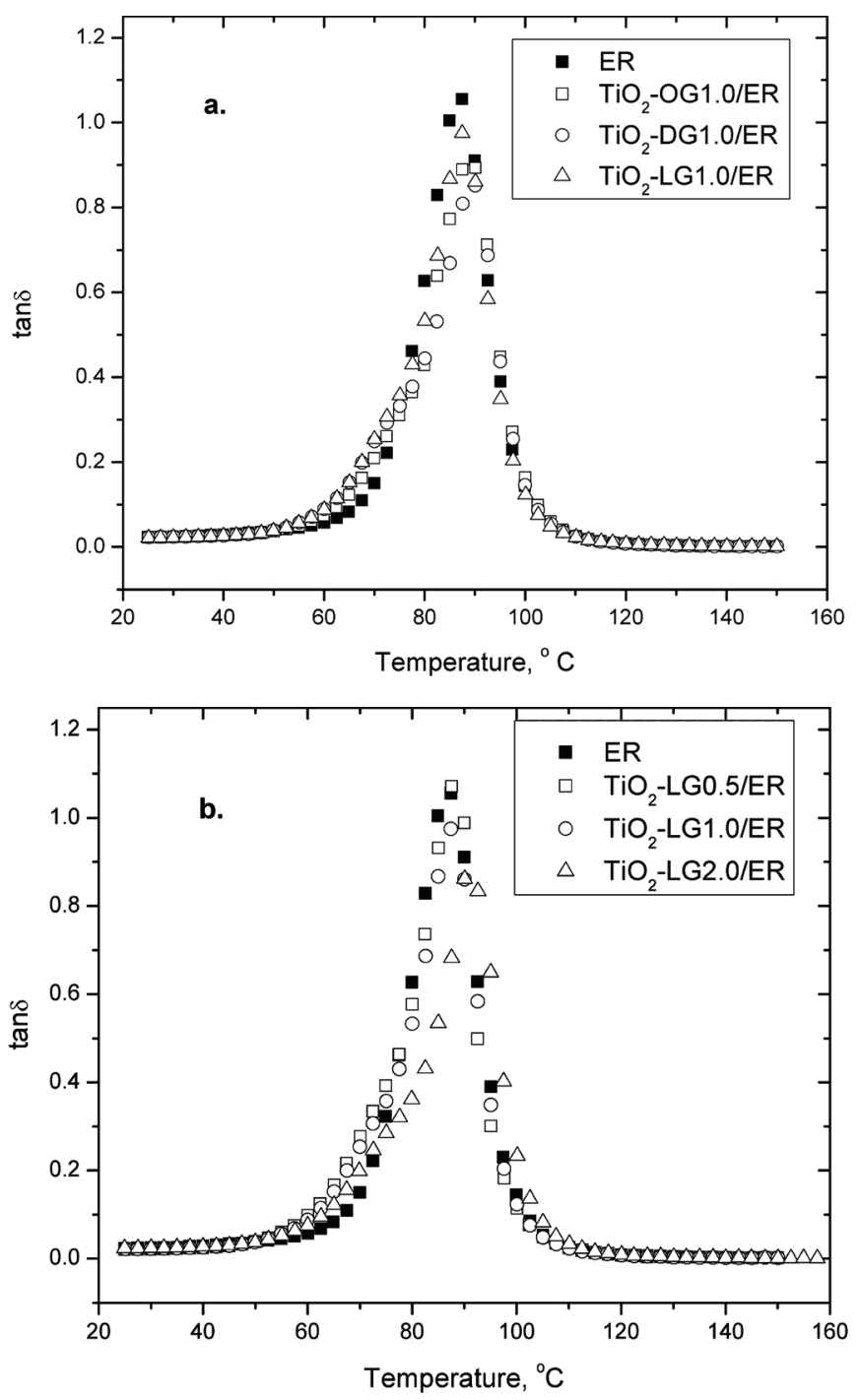

Figure 8. The dependence of loss peak, tan $\delta$, on the temperature for epoxy resin and a) $\mathrm{TiO}_{2}-\mathrm{OG} 1.0 / \mathrm{ER}, \mathrm{TiO}_{2}-\mathrm{DG} 1.0 /$ ER and $\mathrm{TiO}_{2}$-LG1.0/ER and b) $\mathrm{TiO}_{2}$-LG0.5/ER, $\mathrm{TiO}_{2}$-LG1.0/ER and $\mathrm{TiO}_{2}-\mathrm{LG} 2.0 / \mathrm{ER}$ nanocomposites

Hardness of the prepared coatings

The values of thickness and König pendulum hardness of $\mathrm{TiO}_{2}$ /epoxy films are shown in Table 2. These tests were carried out on cured coatings drawn on glass plates. The measured hardness values for all tested samples are approximately the same which means that the presence of the surface modified $\mathrm{TiO}_{2}$ nanoparticles, as well as the change of the chain length of alkyl gallates used for surface modification of $\mathrm{TiO}_{2}$ nanoparticles and their content had no significant effect on the hardness of the coatings based on epoxy resin. 
Table 2. Values of the dry film thickness, König hardness and water vapor transmission rate, WVTR, of the examined samples

\begin{tabular}{lccc}
\hline Sample & $\begin{array}{c}\text { Film } \\
\text { thickness, } \mu \mathrm{m}\end{array}$ & $\begin{array}{c}\text { Hardness, } \\
\text { osc }\end{array}$ & $\begin{array}{c}W V T R, \\
\mathrm{~g} / \mathrm{m}^{2} \mathrm{~h}\end{array}$ \\
\hline $\mathrm{ER}$ & 65 & 152 & 0.539 \\
$\mathrm{TiO}_{2}$-OG1.0/ER & 65 & 149 & 0.502 \\
$\mathrm{TiO}_{2}$-DG1.0/ER & 55 & 147 & 0.491 \\
$\mathrm{TiO}_{2}$-LG0.5/ER & 55 & 148 & - \\
$\mathrm{TiO}_{2}$-LG1.0/ER & 70 & 152 & 0.489 \\
$\mathrm{TiO}_{2}$-LG2.0/ER & 70 & 152 & - \\
\hline
\end{tabular}

Water vapor permeability of the synthesized $\mathrm{TiO}_{2} /$ epoxy nanocomposites

One of the basic properties of organic coatings is to protect the underlying substrate from aggressive agents, especially from water. The incorporation of inorganic particles into polymers is one of the most common approaches to improve the barrier properties of polymers. The barrier properties of nanocomposites can be improved by the adequate surface modification of nanoparticles which leads to uniform distribution of nanoparticles in the polymer matrix and a better interfacial interaction of nanoparticles and the polymer matrix. Good adhesive interface interactions give compact and a pore free microstructure, which leads to the reduction of the water vapor penetration. The strong attractive interactions at the interface increase $T g$ and reduce free volume, contributing in this manner to better barrier properties. Also, the reduction of free volume and the improvement of barrier properties can be achieved by chemical bonding of nanoparticles to the polymer matrix [6, 34].

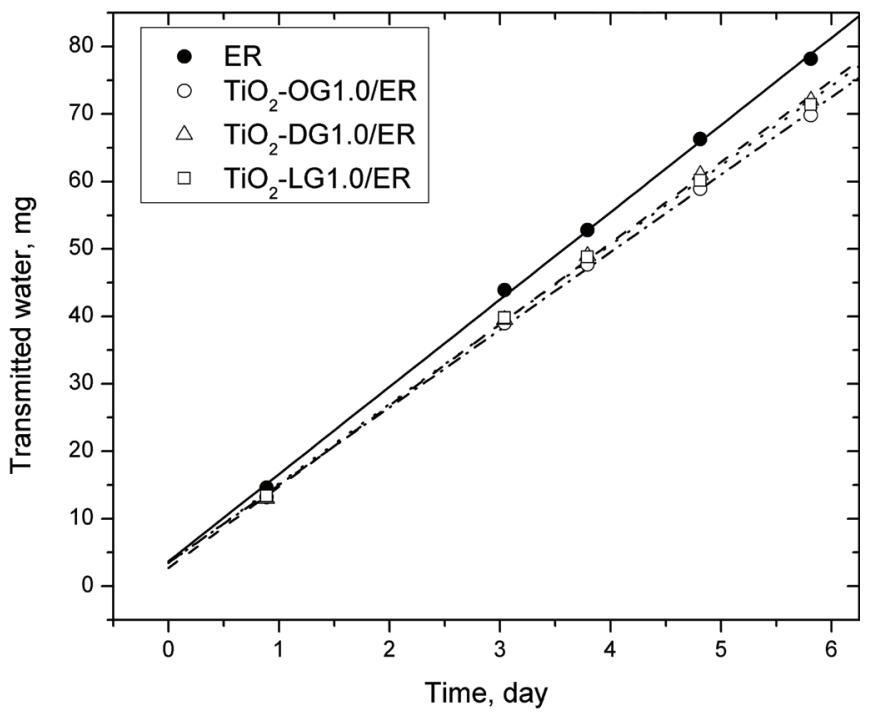

Figure 9. The dependence of the water transmitted through the examined films on time

Water vapor permeability of the prepared samples was investigated by the gravimetric measuring technique that determines the total water vapor transport through the epoxy films by measuring the gain of the sample mass (ASTM D1653-13). The influence of the surface modified $\mathrm{TiO}_{2}$ nanoparticles on the permeability of the epoxy resin was tested using the permeability cup desiccant method. The amount of water, passed through the epoxy films as a function of time is shown in Figure 9. Water vapor transmission rate $(W V T R)$ of the $\mathrm{TiO}_{2} /$ epoxy films was calculated using the slope of the linear fit of change of passed water mass vs. time. The obtained values are presented in Table 2. The water vapor transmission rate of neat epoxy resin has the highest value. Incorporation of the surface modified $\mathrm{TiO}_{2}$ nanoparticles in epoxy resin decreased the WVTR. Also, it was observed that WVTR of $\mathrm{TiO}_{2} /$ epoxy films decreased with the increase of the alkyl chain length of gallate ligand.

\section{Conclusions}

$\mathrm{TiO}_{2}$ nanoparticles, prepared by hydrolysis of titanium isopropoxide, were surface modified with three gallic acid esters, having different chain lengths of the hydrophobic part: octyl, decyl and lauryl gallate. The surface modified $\mathrm{TiO}_{2}$ nanoparticles were incorporated into epoxy resin and the influence of their presence, the length of the hydrophobic part of gallates, as well as the content of lauryl gallate used for the surface modification of $\mathrm{TiO}_{2}$ nanoparticles on glass transition temperature, rheology, barrier properties and hardness of epoxy resin was investigated.

The formation of a charge transfer complex between the $\mathrm{TiO}_{2}$ nanoparticles and gallates was confirmed by FTIR and UV-Vis spectroscopy. Incorporation of the surface modified $\mathrm{TiO}_{2}$ nanoparticles led to the increase of $T g$ of epoxy resin indicating the presence of attractive interactions between the $\mathrm{TiO}_{2}$ nanoparticles and the polymer matrix and the reduction of polymer segmental mobility at the interface between the polymer matrix and $\mathrm{TiO}_{2}$ nanoparticles. DSC and DMA results also revealed that with increasing the nanofiller content, the glass transition temperature of the prepared nanocomposites slightly increased. The presence of the surface modified $\mathrm{TiO}_{2}$ nanoparticles had no significant effect on the hardness of the coatings based on epoxy resin. The water vapor permeability of epoxy resin was reduced by incorporation of the surface modified $\mathrm{TiO}_{2}$ nanoparticles, indicating that the synthesized epoxy based nanocomposites have better barrier properties than the neat epoxy resin. Furthermore, the obtained results revealed that the water vapor transmission rate of $\mathrm{TiO}_{2} /$ epoxy nanocomposites decreases with increasing the hydrophobic part chain length of gallate ligands.

\section{Acknowledgements}

This work was financially supported by the Ministry of Education, Science and Technological Development of the Republic of Serbia (research Project Number: 172062). 


\section{References}

[1] S.-J. Park, F.-L. Jin, J.-R. Lee, Thermal and mechanical properties of tetrafunctional epoxy resin toughened with epoxidized soybean oil, Materials Science and Engineering: A, 374(1-2) (2004) 109-114.

[2] Q. M. Jia, M. Zheng, C. Z. Xu, H. X. Chen, The mechanical properties and tribological behavior of epoxy resin composites modified by different shape nanofillers, Polymers for Advanced Technologies, 17(3) (2006) 168173.

[3] H. A. Al-Turaif, Effect of nano $\mathrm{TiO}_{2}$ particle size on mechanical properties of cured epoxy resin, Progress in Organic Coatings, 69(3) (2010) 241-246.

[4] S. Farrokhpay, A review of polymeric dispersant stabilisation of titania pigment, Advances in Colloid and Interface Science, 151(1-2) (2009) 24-32.

[5] A. Chatterjee, M. S. Islam, Fabrication and characterization of $\mathrm{TiO}_{2}$-epoxy nanocomposite, Materials Science and Engineering: A, 487(1-2) (2008) 574-585.

[6] D. Y. Perera, Effect of pigmentation on organic coating characteristics, Progress in Organic Coatings, 50(4) (2004) 247-262.

[7] M. V. Popa, P. Drob, E. Vasilescu, J. C. Mirza-Rosca, A. S. Lopez, C. Vasilescu, S. I. Drob, The pigment influence on the anticorrosive performance of some alkyd films, Materials Chemistry and Physics, 100(2-3) (2006) 296303.

[8] B. Ramezanzadeh, M. M. Attar, Characterization of the fracture behavior and viscoelastic properties of epoxypolyamide coating reinforced with nanometer and micrometer sized $\mathrm{ZnO}$ particles, Progress in Organic Coatings, 71(3) (2011) 242-249.

[9] B. Ramezanzadeh, M. M. Attar, M. Farzam, A study on the anticorrosion performance of the epoxy-polyamide nanocomposites containing $\mathrm{ZnO}$ nanoparticles, Progress in Organic Coatings, 72(3) (2011) 410-422.

[10] X. Shi, T. A. Nguyen, Z. Suo, Y. Liu, R. Avci, Effect of nanoparticles on the anticorrosion and mechanical properties of epoxy coating, Surface and Coatings Technology, 204(3) (2009) 237-245.

[11] S. M. Mirabedini, M. Behzadnasab, K. Kabiri, Effect of various combinations of zirconia and organoclay nanoparticles on mechanical and thermal properties of an epoxy nanocomposite coating, Composites Part A: Applied Science and Manufacturing, 43(11) (2012) 20952106.

[12] M. Conradi, A. Kocijan, D. Kek-Merl, M. Zorko, I. Verpoest, Mechanical and anticorrosion properties of nanosilicafilled epoxy-resin composite coatings, Applied Surface Science, 292((2014) 432-437.

[13] J. L. H. Chau, C. T. Tung, Y. M. Lin, A. K. Li, Preparation and optical properties of titania/epoxy nanocomposite coatings, Materials Letters, 62(19) (2008) 3416-3418.

[14] A. Allahverdi, M. Ehsani, H. Janpour, S. Ahmadi, The effect of nanosilica on mechanical, thermal and morphological properties of epoxy coating, Progress in Organic Coatings, 75(4) (2012) 543-548.

[15] M. A. Neouze, U. Schubert, Surface modification and functionalization of metal and metal oxide nanoparticles by organic ligands, Monatshefte fur Chemie, 139(3) (2008) 183-195.

[16] E. Ruckenstein, Z. F. Li, Surface modification and functionalization through the self-assembled monolayer and graft polymerization, Advances in Colloid and Interface Science, 113(1) (2005) 43-63.

[17] S. Elbasuney, Dispersion characteristics of dry and colloidal nano-titania into epoxy resin, Powder Technology, 268(0) (2014) 158-164.

[18] S. Kango, S. Kalia, A. Celli, J. Njuguna, Y. Habibi, R. Kumar, Surface modification of inorganic nanoparticles for development of organic-inorganic nanocomposites - A review, Progress in Polymer Science, 38(8) (2013) 12321261.

[19] N. Nakayama, T. Hayashi, Preparation of $\mathrm{TiO}_{2}$ nanoparticles surface-modified by both carboxylic acid and amine: Dispersibility and stabilization in organic solvents, Colloids and Surfaces A: Physicochemical and Engineering Aspects, 317(1-3) (2008) 543-550.

[20] G. E. Morris, W. A. Skinner, P. G. Self, R. S. C. Smart, Surface chemistry and rheological behaviour of titania pigment suspensions, Colloids and Surfaces A: Physicochemical and Engineering Aspects, 155(1) (1999) 27-41.

[21] H. Wu, C. Zhang, Y. Liang, J. Shi, X. Wang, Z. Jiang, Catechol modification and covalent immobilization of catalase on titania submicrospheres, Journal of Molecular Catalysis B: Enzymatic, 92(0) (2013) 44-50

[22] Q. Ai, D. Yang, Y. Li, J. Shi, X. Wang, Z. Jiang, Highly efficient covalent immobilization of catalase on titanate nanotubes, Biochemical Engineering Journal, 83(0) (2014) 8-15

[23] L. Shun-Xing, Z. Feng-Ying, C. Wen-Lian, H. Ai-Qin, X. Yu-Kun, Surface modification of nanometer size $\mathrm{TiO}_{2}$ with salicylic acid for photocatalytic degradation of 4-nitrophenol, Journal of Hazardous Materials, 135(1-3) (2006) 431-436.

[24] I. Janković, Z. Saponjić, E. Džunuzović, J. Nedeljković, New Hybrid Properties of $\mathrm{TiO}_{2}$ Nanoparticles Surface Modified With Catecholate Type Ligands, Nanoscale Research Letters, 5(1) (2010) 81 - 88.

[25] R. Rodrıguez, M. A. Blesa, A. E. Regazzoni, Surface Complexation at the $\mathrm{TiO}_{2}$ (anatase)/Aqueous Solution Interface: Chemisorption of Catechol, Journal of Colloid and Interface Science, 177(1) (1996) 122-131.

[26] E. S. Džunuzović, J. V. Džunuzović, T. S. Radoman, M. T. Marinović-Cincović, L. B. Nikolić, K. B. Jeremić, J. M. Nedeljković, Characterization of in situ prepared nanocomposites of $\mathrm{PS}$ and $\mathrm{TIO}_{2}$ nanoparticles surface modified with alkyl gallates: Effect of alkyl chain length, Polymer Composites, 34(3) (2013) 399-407.

[27] T. S. Radoman, J. V. Džunuzović, K. B. Jeremić, B. N. Grgur, D. S. Miličević, I. G. Popović, E. S. Džunuzović, Improvement of epoxy resin properties by incorporation of $\mathrm{TiO}_{2}$ nanoparticles surface modified with gallic acid esters, Materials \& Design, 62(0) (2014) 158-167.

[28] B. Coppens, B. Sas, H. Johan Van, U. S. Patent WO 2001030299 A3 (2001).

[29] B. O'Regan, J. Moser, M. Anderson, M. Graetzel, Vectorial electron injection into transparent semiconductor membranes and electric field effects on the dynamics of light-induced charge separation, The Journal of Physical Chemistry, 94(24) (1990) 8720-8726.

[30] E. Džunuzović, V. Vodnik, K. Jeremić, J. M. Nedeljković, Thermal properties of $\mathrm{PS} / \mathrm{TiO}_{2}$ nanocomposites obtained by in situ bulk radical polymerization of styrene, Materials Letters, 63(11) (2009) 908-910.

[31] D. Cangialosi, V. M. Boucher, A. Alegria, J. Colmenero, 
Physical aging in polymers and polymer nanocomposites: recent results and open questions, Soft Matter, 9(36) (2013) 8619-8630.

[32] A. Omrani, S. Afsar, M. A. Safarpour, Thermoset nanocomposites using hybrid nano $\mathrm{TiO}_{2}-\mathrm{SiO}_{2}$, Materials Chemistry and Physics, 122(2-3) (2010) 343-349.

[33] M. T. Albdiry, B. F. Yousif, Role of silanized halloysite nanotubes on structural, mechanical properties and fracture toughness of thermoset nanocomposites, Materials \& Design, 57(0) (2014) 279-288.
[34] S. Shreepathi, S. Naik, M. Vattipalli, Water transportation through organic coatings: correlation between electrochemical impedance measurements, gravimetry, and water vapor permeability, Journal of Coatings Technology and Research, 9(4) (2012) 411-422.

\section{Izvod}

\section{SINTEZA I KARAKTERIZACIJA NANOKOMPOZITA NA BAZI POVRŠINSKI MODIFIKOVANIH NANOČESTICA TITAN-DIOKSIDA I EPOKSIDNE SMOLE}

Tijana S. Radoman ${ }^{1}$, Nenad Terzić ${ }^{2}$, Pavle M. Spasojević ${ }^{1}$, Jasna V. Džunuzović ${ }^{3}$, Aleksandar D. Marinković ${ }^{2}$ Katarina B. Jeremić², Enis S. Džunuzović ${ }^{2}$

\footnotetext{
1 Inovacioni centar, Tehnološko-metalurški fakultet, Univerzitet u Beogradu, Srbija

2 Tehnološko-metalurški fakultet, Univerzitet u Beogradu, Srbija

3 Institut za hemiju, tehnologiju i metalurgiju (IHTM) - Centar za hemiju, Univerzitet u Beogradu, Srbija
}

$\mathrm{U}$ ovom radu, $\mathrm{TiO}_{2}$ nanočestice su dobijene kiselo katalizovanom hidrolizom titanijum izopropoksida, a njihova površinska modifikacija izvedena je estrima galne kiseline sa različitom dužinom hidrofobnog dela lanca: oktil, decil i lauril galat. Površinski modifikovane $\mathrm{TiO}_{2}$ nanočestice su zatim korišćene za pripremu $\mathrm{TiO}_{2}$ /epoksi nanokompozita. Karakterizacija površinski modifikovanih $\mathrm{TiO}_{2}$ nanočestica je izvršena pomoću FTIR i UV-Vis spektroskopije. Ispitan je uticaj različitih estara galne kiseline korišćenih za površinsku modifikaciju i sadržaj modifikovanih $\mathrm{TiO}_{2}$ nanočestica na temperaturu ostakljivanja, reološka, barijerna i mehanička svojstva sintetisanih nanokompozita pomoću diferencijalne skenirajuće kalorimetrije, dinamičko mehaničke analize, testa propustljivosti za vodenu paru i König klatna. Prisustvo površinski modifikovanih $\mathrm{TiO}_{2}$ nanočestica u epoksidnoj smoli dovodi do povećanja temperature ostakljivanja i smanjenja propustljivosti vodene pare u poređenju sa čistom epoksidnom smolom. Međutim, različita dužina nepolarnog dela galata nije pokazala uticaj na temperaturu ostakljivanja sintetisanih nanokompozita, dok je povećanje sadržaja nanopunila dovelo do porasta temperature ostakljivanja. Sa povećanjem dužine hidrofobnog dela galata, brzina transporta vodene pare smanjena je za ispitivane nanokompozite, dok se tvrdoća nanokompozitnih prevlaka na bazi epoksidne smole ne razlikuje.
(ORIGINALNI NAUČNI RAD)

UDK 678.743 .2

Ključne reči: $\mathrm{TiO}_{2}$ /epoksi nanokompoziti, površinska modifikacija, estri galne kiseline, propusljivost vodene pare, tvrdoća po König-u 